\title{
SLC45A3 Gene
}

National Cancer Institute

\section{Source}

National Cancer Institute. SLC45A3 Gene. NCI Thesaurus. Code C97791.

This gene plays a role in transmembrane transport. 